\title{
TAXPAYERS' COMPETENCY LEVEL IN GOVERNING GOODS SERVICES TAX (GST) COMPLIANCE: MALAYSIA SCENARIO.
}

\author{
Siti Syaqilah Hambali* and Amrizah Kamaluddin ** \\ Faculty of Accountancy Universiti Teknologi MARA Puncak Alam* \\ Accounting Research Institute Universiti Teknologi MARA Shah Alam ${ }^{* *}$
}

\begin{abstract}
GST implementation in Malaysia in April 2015 is part of the tax reformation with the goal of having a more efficient and effective taxation system. A successful tax reformation requires a high acceptance from taxpayers. In order to aid in the acceptance of GST implementation, taxpayers need to have a good competency level reflected through proper knowledge and awareness of the GST system, also known as GST literacy. Thus, the main objective of this study is to assess the level of GST literacy of taxpayers. Secondly, the current study aims to identify the relationship between GST literacy level with the GST acceptance of the taxpayers. Questionnaires were distributed to 150 secondary school teachers in Johor, one of the states in Malaysia. The finding indicates that the respondents' literacy rate towards the GST implementation in Malaysia is fair. The results imply that secondary school teachers have a moderate knowledge level and high awareness level on GST implementation in Malaysia. The study proves statistically that there is a positive significant relationship between GST literacy with GST acceptance.
\end{abstract}

Keywords: Competency, GST implementation, GST literacy, GST acceptance, GST knowledge and GST awareness

\section{INTRODUCTION}

Goods and Services Tax (GST) is a broad-based tax charged on goods and services in all sectors within the economy. Malaysia has implemented GST to replace the Sales and Services Tax (SST) with effect first April 2015. To this date, more than 160 countries have implemented GST. Out of the 160 countries, 7 countries represents ASEAN, 19 countries are from Asia, 53 countries are from Europe, 7 countries are from Oceania, 44 countries are from Africa, 11 countries are from South America, 19 countries are from Caribbean, Central and North America and the balance are countries that do not belong in United Nation (Royal Malaysia Customs Department).

GST is a non-claimable tax charged to consumers. In other words, the consumers cannot claim tax rebate on their purchase of the goods and services. Meanwhile, for the suppliers of goods and services, they carry the responsibility to collect GST on behalf of the government (Fatt, 2006).

"GST shall be levied and charged on the taxable supply of goods and services made in the course or furtherance of a business in Malaysia by a taxable person. GST is also charged on the importation of goods and services" 
(Royal Malaysia Customs Department)

The proposal to implement GST was made in the Budget Speech 2005 to replace SST which should have taken into effect on 1January 2007. However, the GST implementation was delayed due to many criticisms and non-readiness issues. It was then tabled again on 16December 2009 as the first reading in Dewan Rakyat and then again was delayed (Shamsuddin, Ruslan, Halim, Zahari, \& Fazi, 2014). Subsequently, on 25October 2013, the SixthPrime Minister of Malaysia, Dato' Sri NajibTunRazak in the Budget presentation 2014 has announced that the GST will take effect on 1 April 2015.

\section{PROBLEM STATEMENTS}

The GST implementation in Malaysia is expected to have an impact on the price of the goods and services. It is also expected to affect the lower income consumers' purchasing power, an increase in the tax rate and an increase in the government responsibility in utilising GST money (Narayanan, 2014). Such impacts have been discussed and established in other countries and as such, it is expected that Malaysia may likely be facing the same experience. Therefore, the Malaysian government needs to take appropriate measures to alleviate these impacts once GST is implemented. Consideration needs to be made particularly on the link between the price of the goods and services and the income level of the consumers. It is expected that the increase in price of goods and services would reduce the lower income consumers' purchasing power. The significant increase in the price of goods and services such as transportations which are commonly used by the middle and lower income earners would impact their financial conditions (Narayanan, 2014).

Studies have shown that the public in general have limited knowledge and lack of awareness on the various kinds of tax in Malaysia. The public are also unaware of how the government utilises the tax money for true expenditure (Moomal and Zakaria (2014). Such lacking of GST knowledge might lead to a false calculation of GST charged by the businesses that wanted to deceit their customers. Of consequence, GST evasion cases would increase and the government would experience a low tax collection. In addition, the various GST charges may also confuse the public. The effectiveness of disseminating information on GST system to the public should be emphasized to enhance GST compliance and effectiveness. Sufficient knowledge is an essential requirement to gain the public acceptance and enhance compliance in achieving successful GST implementations. Therefore, knowledge in GST system is important to increase the public literacy, acceptance and confidence.

It is evident that to obtain the public attention and acceptance of GST, the country may find difficulty in achieving consensus among the public due to its large population. According to Mansor and Ilias (2013), changes can be difficult without proper preparation and resistance often occurs when changes take place. However, such resistance can be changed by addressing the mind-set of the public particularly the taxpayers. While, developing a new system is one of important preparation for GST and will involve in computerized accounting system for changes to take place.

Literally, the Malaysia public is at doubt and may not be easily convinced because of the different thinking and perspectives, and different political backgrounds either from the opposition parties or among the public. The pivot deal that always being discussed is how GST system benefits or harms them. Mansor and Ilias (2013) suggested that the acceptance of a new

\footnotetext{
*Corresponding author's email: syaqilah9972@salam.uitm.edu.my
} 
tax reform can be alleviated through providing strong efforts in convincing the consumers by way of educating and explaining clearly how GST works and benefits them in a long run. Arguably, the importance of literacy on GST system among consumers is important.

The literacy level on GST among the public is evident because it leads to the acceptance of this tax reformation made by the government. There are several studies in the accounting literature that have reported that tax literacy among the Malaysians on average is still at medium level (Bhushan \& Medury, 2013; Kamaluddin \& Madi, 2005; Latiff, Noordin, Omar, \& Harjito, 2005; Madi et al., 2010). It is worth to note that the responsibility in increasing the tax literacy among the people does not lie entirely in the government's hands. It is a shared responsibility in which the basic knowledge should be provided as early as possible since taxation is a universal knowledge that is applicable throughout the world.

Arguably, tax education should not only focus on students in the accounting and business related disciplines but also include students in other disciplines (Palil, Akir, \& Ahmad, 2013). This is because these students will eventually become taxpayers in the future and therefore, are also in need of knowledge in taxation. In order to develop knowledgeable taxpayers, education from an early stage is necessary. Therefore, teachers' tax literacy should be developed in order to ensure that the secondary school students will received sufficient and useful information on taxation. In the future, taxpayers will be more opened up towards the taxation system as they have been educated earlier.

Palil et al. (2013) noted that literate taxpayers require sufficient tax knowledge and this knowledge should be provided starting from the early education in schools and not when they have enrolled in the tertiary level. GST knowledge is part of the tax education. Gaining GST knowledge should not only be the responsibility of the consumers but also is the responsibility of the companies. In order to increase the compliance rate among the companies, consumers and the public as a whole, they need to possess GST knowledge as early as possible. Once they have become the taxpayers or run their own businesses, they would be able to comply with at least the basic stage of taxation and of consequence, lead to higher compliance rate in Malaysia.

A group of studies have found that the awareness towards GST implementation in Malaysia is at a medium level (Latiff et al., 2005; Moomal \& Zakaria, 2014; Palil \& Ibrahim, 2011; Saira, Zariyawati, \& Yoke-May, 2010; Shamsuddin et al., 2014). Among the reasons to such lack of awareness are lack of understanding and knowledge and this in turn has led them to oppose and reject GST implementation (Saira et al., 2010). The false concept of awareness in underestimating tax load and overestimating tax burden (Cullis \& Jones, 1992) has provide further misconception on this new tax requirement (Saira et al., 2010).

\section{LITERATURE REVIEW}

GST in Malaysia works with the standard rate of $6 \%$ of the goods and services. Companies with annual turnover exceeding RM500, 000 are mandatory to register GST and collect the tax on behalf of the government. Voluntary registration of GST can be performed by the companies to charge GST on the goods and services provided that companies remain in the system for at least 2 years. However, to avoid over burdening the consumers, the government has taken the initiative to categorise the GST into three main categories. (refer table 1)

Table 1: Three Categories of GST

\footnotetext{
*Corresponding author's email: syaqilah9972@salam.uitm.edu.my
} 


\begin{tabular}{ll}
\hline Categories & Examples \\
\hline 6\% GST & For all items that not listed as GST exempted or zero-rated supply items. \\
& $\begin{array}{l}\text { Foods items: Rice, flour, sugar, cooking oils, spices, white bread and whole meal bread, coffee } \\
\text { powder, tea dust, cocoa powder, yellow mee, kueyteow, seafood and other unprocessed foods. }\end{array}$ \\
& Agriculture products and livestock's: Paddy, fresh vegetables, fruits, cows, goats, poultry. \\
& Utilities and export: Water supply (domestic), electric supply for the first 300 units (domestic), \\
& goods and services exported. \\
& $\begin{array}{l}\text { The national essential medicines: } 2900 \text { medicines brands and medicines to treat } 30 \text { types of } \\
\text { diseases such as heart failure, diabetes, high blood pressure, cancer and etc. }\end{array}$ \\
& $\begin{array}{l}\text { Reading materials: Child's colouring book, textbooks, dictionary, religious book, newspaper and } \\
\text { exercise and reference book. }\end{array}$ \\
& $\begin{array}{l}\text { Public Transport: Rail services, bus services, taxi services, toll highways and bridges and water } \\
\text { transportation services. } \\
\text { Housing loans: Sales and purchase / lease of residential property, agriculture land and land for } \\
\text { general use }\end{array}$ \\
Other services: Private healthcare and education services, selected financial services
\end{tabular}

(Royal Malaysia Customs Department, 2015)

In recent years, Malaysian researchers have shown great interest in researching GST. To this date, Malaysia is the latest country to implement GST. Research on the effectiveness of GST is among the highest areas that received interest among researchers in the accounting field. Studies (Benge, Pallot, \& Slack, 2013; Breen, Bergin-Seers, Roberts, \& Sims, 2002; Hooper \& Smith, 1997; James, 2000; James \& Alley, 2008; Jenkins \& Khadka, 1998; McGowan \& Billings, 1997) in other countries have focused on the effectiveness and benefits of GST implementation to the consumers, companies and the country.

\section{GST Literacy}

According to the United Nations Education, Scientific and Cultural Organisations (UNECSO), literacy is defined 'as a person that can understand a content and writing a simple note from his reading' (Latiff et al., 2005, p. 2). On the other hand, illiterate person can be defined as the inability of a person to read and write a simple note for his own benefits. Following the definition, this study refers literacy as the ability of a person to read and understand GST system in Malaysia.

Latiff et al. (2005) defined tax literacy as 'one who own sufficient ability to read, write and understand tax matters'. Madi and Kamaluddin (2003) defined literacy as 'the ability to fill the tax form and calculate their tax liabilities independently'. In another study, Kamaluddin and Madi (2005, p. 6) extended their definition of a literate taxpayer as 'having an average understanding of basic tax knowledge but need assistance in determining their tax liability'. Another studies by Bhushan and Medury (2013, p. 76) defined tax literacy as 'knowledge possess by individual to manage the issues concerning their personal taxation effectively'.

Mahdavi (2008) concluded that improving tax literacy rate can increase the level of taxation because he found that a high level of education has a positive affect towards sales and excise taxes. On the other hand, there is positive relationship between the effective literacy rates on tax revenues (Book, 2003). The maverick taxpayers may use the advantage of difference in 
taxes and languages in conducting tax evasion thus this will reduces tax revenues book (Book, 2003). High tax literacy can eliminate tax evasion, thus brings revenue to the country. A successful tax system can be maintained by developing tax literacy among the taxpayers to obtain information about domestic or international tax system (James, 2000).

In the context of taxation, many researchers (Bhushan \& Medury, 2013; Book, 2003; James, 2000; Kamaluddin \& Madi, 2005; Latiff et al., 2005; Mahdavi, 2008) as discussed above have defined tax literacy as related to the process of completing tax return from either corporate or individual tax liability since it is one of the major tax contributors to the government that affects the government financially. In brief, this study will examine the tax literacy in the perspective of GST.

\section{GST Knowledge}

Knowledge is defined as 'an information, understanding and skills that gain through learning and experience' (Oxford Student's Dictionary of English, 2007). Following this definition, this study refers knowledge as the information and understanding on GST implementation as part of the taxation system in Malaysia where the knowledge of taxation has become a major need for all taxpayers and potential taxpayers (Bardai, 1992). Tax knowledge such as charging GST on items, paying income tax and etc. is also required by businesses in their transactions. Tax knowledge that needs to be understood by businessman is because their daily business transactions include collecting in charging tax money to the customers or from the suppliers. Many companies in Malaysia realise that GST system is complex and they lack of knowledge in GST system at using the correct policies and rate in their business transactions (Palil, Ramli, Mustapha, \& Hassan, 2013). The complexity may harm the successful of implementation process and may increase the rate of tax evasions.

The introduction of a new tax system such as self-assessment system beforehand requires the taxpayers to obtain sufficient tax knowledge (Loo, Evans, \& McKerchar, 2010). Arguably, this can be applied to GST introduction. Saira et al. (2010) conducted a study to explore the GST awareness in Malaysia. They found that $95 \%$ of the respondents are aware that tax is one of the major incomes for the government. The respondents who are from the accounting and nonaccounting background possessed a high percentage of basic taxation knowledge. Since the findings show that the knowledge on basic taxation is high, Saira et al. (2010) indicated that the respondents with an accounting background are aware of GST. They also found that having a basic tax knowledge would lead to a different level of understanding on GST among the respondents. They also found that the respondents have a balance understanding on GST since they are unable to define GST in general and are unable to identify the GST rate proposed by the government. Their findings indicated that having a basic knowledge of taxation is not sufficient to explain a person's level of understanding on the tax system.

Prior to the implementation of GST in Singapore, the government has taken an initiative to educate their taxpayers by providing various programs related to the rational and effect of GST to the public and businesses. The first program was getting the businesses ready (Jenkins \& Khadka, 1998). Various programs were conducted such as dialogues and seminars between the Inland Revenue Authority of Singapore (IRAS) and the trade associations in Singapore. The purpose of the programs was to obtain input from the businesses on their actual business activities in order to design the GST system. The feedbacks gathered from the seminars and dialogues have assisted the government in tuning the GST system to meet the needs and conditions of the consumers and local businesses. A special GST division was established to examine the special aspects of specialised industries activities to avoid dispute before the GST *Corresponding author's email: syaqilah9972@salam.uitm.edu.my 
was implemented. Other programs were conducted to educate the public on GST (Jenkins \& Khadka, 1998). IRAS also took the initiatives to educate the young college students and local officers so that they could explain and resolve disputes among family members who are also the consumers.

\section{‘GST Awareness}

Moomal and Zakaria (2014) defined awareness as the action context of a person imparted from the level of understanding upon certain activities. The general definition of awareness is a consciousness or interest (Oxford Student's Dictionary of English, 2007). Following this definition, this study defines awareness as the interest of the taxpayers towards understanding GST implementation in Malaysia. Cullis and Jones (1992) identified two types of awareness among the public namely, optimistic and pessimistic. Optimistic refers to the underestimation of tax load by the public servers whilst pessimistic refers to the overestimation of tax burden (Moomal \& Zakaria, 2014).

Saira et al. (2010) have also examined the awareness of GST between respondents with accounting background and respondents without accounting background. They found a different level of awareness where $95.74 \%$ of the respondents with accounting background are aware and understand GST. This is understandable since tax education is one of the subjects taught in accounting courses. The awareness is naturally developed based on the understanding and knowledge among the respondents with accounting background (Fatt, 2006). However, Moomal and Zakaria (2014) found that respondents with low education level are more aware of GST compared to the respondents with high education level.

Shamsuddin et al. (2014) examined the educators' awareness on GST implementation. Their results showed that $93.8 \%$ of the respondents are aware of GST proposed by the government. However, only $79.6 \%$ of the respondents understand why GST needs to be implemented in Malaysia. They concluded that acceptance of GST can only be achieved when the educators fully understand GST.

Al-Mamun et al. (2014) found that a significant negative relationship between the respondents' awareness and education level. In other words, the respondents' high level of education leads to a lesser awareness on GST. In contrast, Moomal and Zakaria (2014) found a no significant relationship between education level and awareness level although they found the acceptance level of GST varies among the respondents.

Moomal and Zakaria (2014) found that $76 \%$ their Malaysian respondents are aware of GST. The overall mean score of awareness level among the respondents showed a moderate to low level of awareness. The reasons to the low level of awareness are fear of price increases, occurrence of inflation, lack of information and unclear objectives (Moomal \& Zakaria, 2014). However, their study was conducted before GST was implemented. The results may be different if the study had been conducted after the GST implementation. This is because awareness on GST may increase from time to time since certain GST issues may have been solved and some new issues may have also emerged. Of consequence, this may influence the public interest towards GST and affect their awareness. 


\section{GST Acceptance}

GST is part of the tax system which is not recent and it shares the same concept as VAT. As in other tax systems, there would be people opposing to GST implementation. Benge et al. (2013) claimed that in gaining the public acceptance on tax system, the system must prove to be beneficial to the low-income families and beneficiaries, and a subsequent tax reformation process.

In Malaysia, GST implementation has faced some difficulties in terms of acceptance from the public (Choo, 2014; Fadzell, 2015; The Star Online, 2013). This calls for the government to strategise ways to inform the public on the benefits of GST in order to protect their revenue and enhance the tax system. It is clear that the government would not impose a policy that is not beneficial to the public and the country. The GST implementation in April 2015 may cause evasion and a burden to the average income earners (The Star Online, 2013). The consumers need to know which goods and services are not taxable and the exclusion list must be clear. Enforcement would ensure that the entire groups of profit-making organisations do not take advantage on this issue. Nurhayati, Halimatusadiah, and Diamonalisa (2015) added that 'a successful VAT/GST system depends upon proper planning and preparation, sound accounting practices, systematic organizational audit, fully acceptance of people, trained manpower, sound ethical business practices in business and ethical government representatives' (Nurhayati et al., 2015, p. 148).

Shamsuddin et al. (2014) found that the educators' acceptance towards GST implementation in Bandar Muadzam Shah Pahang is moderate. In relation to the mean score of the individual acceptance items, all items were above the average mean scores indicating that the educators are in between moderate to high acceptance level. However, Saira et al. (2010) provided a contrasting finding when investigating GST awareness in Malaysia. Their results showed $60.53 \%$ of the respondents oppose GST implementation in Malaysia and surprisingly, $66.67 \%$ out of the $60.53 \%$ of the respondents who oppose GST implementation are with an accounting background. Their results also showed that a high percentage of agreement on GST implementation was found from non-accounting background. They found that the respondents oppose to GST implementation was influenced by the increase in the price of goods and services. Such perception comes mainly from the low-income earners. Furthermore, Ahmad, Ahmad, and Alwie (2015) concluded that perceptions among Malaysian have a significant strong association with acceptance. However, interestingly, this is contrary to a study conducted by Olatunji (2013) where the perception of Nigerian on VAT has no significance effect on its acceptance.

Palil, Akir, et al. (2013) conducted a survey among enterprises in Malaysia on GST acceptance. They found that due to the low level of readiness, the acceptance level among the enterprises is still very low. The enterprises are not ready to accept GST due to lack of understanding GST as they perceived GST implementation would lead to high compliance cost. They concluded that only $17 \%$ of their respondents have purchased the GST system software during the training sessions.

Low level of acceptance among the consumers was also found in Palil and Ibrahim (2011) and Moomal and Zakaria (2014). Palil and Ibrahim (2011) conducted their study using middle income earners located in the big cities in Malaysia. Only $12 \%$ of the respondents accept GST even though they were not aware of GST implementation and 39\% of the respondents accept GST provided that they are aware of the GST implementation. Such low level of acceptance is 
due to the perception that GST would increase their cost of living. Meanwhile, Moomal and Zakaria (2014) in their study on GST acceptance of Malaysian consumers found a moderate to low level of acceptance $(53.5 \%)$. Such resistance could be attributed by the fear of price increased. The consumers also perceived that they received less information and were not clear on the purpose of GST implementations in Malaysia.

In New Zealand, a uniform rate approach of broad based GST system has influenced the acceptance level in the country. It becomes a moderating factor to the economy, help the poor and proven to reduce a number of special cases (Benge et al., 2013). The implementation of GST in New Zealand has received a quick acceptance among the public. Prior to GST implementation, 30 to $35 \%$ of public approval was obtained and the acceptance level increased to $65 \%$ two weeks after implementation (Benge et al., 2013; Breen et al., 2002). The high level of acceptance has largely come from a comprehensive publicity, education campaign and identified potential problems.

The government of New Zealand has provided duration of time for planning purpose before GST implementation took place. The GST Coordinating Office started to develop and coordinate the GST system for the country. The factors considered in implementing GST are overseeing the initiatives in the GST progress that focus on business needs, conducted a program for business and general public as a whole, and fairly view the misunderstanding on GST system and law in all aspects (Breen et al., 2002). These factors are seen to have provided a smooth transition in the introduction period despite the negative perception among the lower revenue companies due to lack of understanding GST. The lower revenue businesses felt that GST implementation is burdensome and unfair. Therefore, the burden and unfair treatment felt at all levels of income can influence the success of GST system either the public or companies and subsequently, low acceptance level.

Meanwhile, Singapore has its own strategy in gaining public acceptance towards GST implementation. GST was introduced in 1994 at 3\% which is considered a low rate and this rate was not raised within the next 5 years. An increased in tax rate started in 2003 at 4\% and then was further raised in 2007 to $7 \%$ (Narayanan, 2014). They started at a low level of tax rate in order to gain public acceptance due to their acknowledgment that public trust would influence the success of new tax reformation process in Singapore. The introduction of GST was supported by the reduction in income tax rate and property tax rate. GST was also introduced at a low rate because Singapore has a stable economy and thus, did not require additional funds to govern the country during that time. In addition, the increase in the GST rate provides an offset to the lower middle income levels such as GST Voucher Scheme and to the companies such as tourist refund scheme and special scheme related to export to minimise its impact at the early implementation stage (Jenkins \& Khadka, 1998). The developed countries have made Singapore a benchmark for GST system. Therefore, Malaysia government can take the success initiative from New Zealand and Singapore in structuring their tax system in order to achieve high acceptance from the citizen.

\section{GST Literacy and Relationship with GST Acceptance}

The current study focuses on knowledge and awareness as proxies to literacy. Kamaluddin and Madi (2005) in their survey of tax literacy of knowledge possessed by individuals on personal tax have found that their respondents have a low level of knowledge towards tax compliance. On the other hand, Palil, Akir, et al. (2013) has examined the role of religiosity in relation to 
the tax education and tax knowledge towards tax compliance. They found no significant relationship between tax education and tax compliance but a significant relationship between tax knowledge and tax compliance. This indicates that knowledge is a major determinant of tax compliance but not education level. Therefore, a negative perception on GST would probably come from the low level of knowledge which indirectly affects the acceptance level of GST implementation (Ahmad et al., 2015; Shamsuddin et al., 2014). Research finding by Bardai (1992) also points towards 30-50\% of taxpayers in Malaysia are illeterate and it is associated with inadequate tax knowledge.

Using a questionnaire survey, Saira et al. (2010) found that the GST awareness among the respondents in Malaysia are inconsistent. They found that the respondents have a poor understanding of GST that led them to oppose GST implementation. The awareness among the public on GST needs to be raised in order to alleviate the misconception of GST attributed by the contradiction of optimistic and pessimistic awareness. Failure to rectify the misconception would influence the public acceptance towards GST. More recent study done by Ahmad et al. (2015) have confirmed that government effort in increasing the awareness towards GST among Malaysian has a strong association with consumers understanding on GST and their level of willingness in accepting GST. In addition, taxpayers' knowledge gains either in formal or nonformal education will have a positive impact on awareness level of taxpayers (Nurhayati et al., 2015).

\section{RESEARCH METHOD}

This study chose secondary school teachers who are currently working in BatuPahat, Johor Darul Takzim as the sample study. Secondary school teachers are chosen because previous study (Bahari \& Ling, 2009) has only focused on educators in the higher institutions. No studies have examined the GST system from the perspective of the secondary school teachers. Since secondary school teachers are also GST taxpayers and contribute to the government's revenue through GST, this sample seems suitable. This study adopted the quantitative data analysis technique. This study also engaged in both descriptive and inference statistics. The primary data was collected through questionnaire survey. The questionnaires were distributed to secondary school teachers in BatuPahat. 91 valid data was then used for further research analysis. This study comprises of 4 variables namely GST acceptance, and GST literacy, where there are 2 dimensions of GST literacy namely GST knowledge and GST awareness. . In this study, 150 questionnaires were distributed to the respondents. Out of 150 questionnaires, 100 questionnaires were returned. From the returned questionnaires, 2 sets were rejected due to incomplete answers, resulting in $65.33 \%$ response rate.

\section{RESULTS AND DISCUSSION}

The reliability of indicators in the questionnaire survey in this study was measured by using the interim consistency reliability of Cronbach's alpha coefficient.

Table 2: Table of Reliability Statistics of Each Variable

\begin{tabular}{lll}
\hline Items & Cronbach's Alpha & N of Items \\
\hline
\end{tabular}

*Corresponding author's email: syaqilah9972@salam.uitm.edu.my 
GST Knowledge

GST Awareness

GST Acceptance
0.726

0.699

0.925

13

9

13

Table 2 presents the reliability statistics of each variable. The result illustrates the reliability test of each variable. Each variable has a Cronbach's alpha coefficients of above 0.6. According to Sekaran and Bougie (2013), if the alpha value of a variable is within the range of 0.6 to 0.79 , then the measurement is considered acceptable. Therefore, the results of GST knowledge and GST awareness indicators in this study are considered reliable for further analysis. The Cronbach alpha of GST acceptance presents a high coefficient level at 0.925 . This indicates that this variable is good in its internal consistency and reliable for further analysis.

\section{The mean analyses of GST Literacy and GST acceptance}

Table 3 shows that the total mean score was then converted into percentage scale in order to measure the literacy level as defined and used by Kamaluddin and Madi (2005).

Table 3: Description of GST Literacy Levels

\begin{tabular}{cc}
\hline Mean Total Percentage & Literacy Level \\
\hline $0 \%-24 \%$ & Very illiterate \\
$25 \%-49 \%$ & Illiterate \\
$50 \%-74 \%$ & Literate \\
$75 \%-100 \%$ & Very literate \\
\hline
\end{tabular}

Source: Kamaluddin and Madi (2005)

This study adapts the measurement of GST acceptance from Shamsuddin et al. (2014). The Likert-scale statements in the questionnaire were analysed in mean and using the total mean score shown in Table 3.3 to determine the level of acceptance.

Table 4: Description of GST Acceptance level

\begin{tabular}{cc}
\hline Total Mean Score & Acceptance Level \\
\hline $42-65$ & High \\
$22-41$ & Moderate \\
$1-21$ & Low \\
\hline
\end{tabular}

Source: Shamsuddin et al. (2014)

GST literacy is measured based on the mean scores of the GST knowledge and GST awareness. Meanwhile, GST acceptance is measured based on 13 indicators tested to determine the level of acceptance towards GST implementation in Malaysia.

Table5: Mean Score analyses of GST Literacy and GST Acceptance

\begin{tabular}{lll}
\hline No & Variables & Mean \\
\hline
\end{tabular}




\begin{tabular}{lll}
\hline $\mathbf{1}$ & GST Literacy mean score & 3.37 \\
$\mathbf{2}$ & GST Acceptance summated mean score & 33.38 \\
\hline
\end{tabular}

Based on Table 5, the result shows that the mean score for GST literacy is 3.37 over Likert Scale of 5. This study GST knowledge and GST awareness dimensions in measuring GST literacy. According to Kamaluddin and Madi (2005) GST literacy level in table 3, the result suggests that the secondary school teachers as the taxpayers are literate taxpayers (literacy level $3.37 / 5=67.4 \%$ ). Such result indicates that they have an average knowledge on GST but in need of more assistance to understand the GST system in Malaysia (Kamaluddin \& Madi, 2005). They are also in need of assistance from the government to increase the public awareness on GST implementation in Malaysia so that their students will become literate in future. This study concludes that the secondary school teachers are literate towards GST implementation in Malaysia.

The Likert-scale responses provided by the respondents for the indicators in the questionnaire survey were then summated to obtain an overall mean score and subsequently divided into three levels. The results depict that the GST acceptance overall total mean score is 33.38 (refer table 5), a result that falls under moderate acceptance (refer table 4). Thus, such result indicates that the secondary school teachers have a moderate acceptance towards GST implementation in Malaysia. Similar result was found in Shamsuddin et al. (2014) and Moomal and Zakaria (2014)on the moderate acceptance of GST implementation among the Malaysian consumers. This study concludes that the secondary school teachers have a moderate acceptance level towards GST implementation in Malaysia.

Table 6 presents the summary of Pearson correlation results of GST knowledge, GST awareness, GST literacy and GST acceptance. The result indicates that GST awareness has a positive correlation with GST awareness of $r=0.457$ at a significant level of 0.01 . As for GST literacy, the result shows a significant positive correlation with GST knowledge $(r=0.852)$ and GST awareness $(r=0.855)$ whilst for GST acceptance, the result shows a significant positive correlation with GST knowledge $(\mathrm{r}=0.371)$, GST awareness $(0.375)$ and GST literacy $(0.437)$ respectively at a significant level of 0.01 .

Table 6: Pearson Correlation Test

\begin{tabular}{lllll}
\hline & GST Knowledge & GST Awareness & GST Literacy & GST Acceptance \\
\hline GST Knowledge & 1 & 1 & \\
GST Awareness & $0.457^{* *}$ & $0.855^{* *}$ & 1 & \\
GST Literacy & $0.852^{* *}$ & $0.375^{* *}$ & $0.437^{* *}$ & 1 \\
GST Acceptance & $0.371^{* *}$ & & \\
\hline
\end{tabular}

Note: **Significant at 0.01 level

In sum, the correlation coefficients between all variables show positive significant correlations. Such result indicates that a high level of literacy reflect the level of GST acceptance. That is high level of literacy is associated with high level of GST knowledge and GST awareness.

Table 7:Multiple Regression Results

\begin{tabular}{llll}
\hline Variables & Coefficient & T-statictics & P-value \\
\hline
\end{tabular}

*Corresponding author's email: syaqilah9972@salam.uitm.edu.my 


\begin{tabular}{lccc}
\hline Intercept & -0.524 & -0.753 & 0.453 \\
GST knowledge & $0.455^{* * *}$ & 2.344 & $0.021^{* *}$ \\
GST awareness & $0.462^{* * *}$ & 2.406 & $0.018^{* *}$ \\
R & 0.191 & & \\
Adj. R & 0.173 & & \\
F-statistics & 10.382 & & \\
\hline
\end{tabular}

Note: $* * *$ significant at 0.01 level

Table 7 shows that the R-square of GST knowledge and GST awareness explains $19.1 \%$ of the GST acceptance. In this study, the adjusted R-square 0.173 or $17.3 \%$ indicates that regression model explains as $17.3 \%$ of the variance in GST acceptance. The model is moderately fit and can predict GST acceptance. According to Muijs (2004) rule of thumb, the adjusted R-square range of 0.11-0.3 is considered as moderately fit model. Therefore, the model proposed for this study can be considered as fit to be used in examining the relationship between independent variables and dependent variable.

The result also shows the f-value of 10.382 of p-significant at 0.00 . Since the p-significant value is less than 0.05 , the model is considered as significant in predicting the GST knowledge and GST awareness on GST acceptance on GST implementation in Malaysia.

This study indicated that there is a significant relationship between the GST literacy and GST acceptance. The results signified the dimensions of GST literacy having positive significant relationships between the GST knowledge with GST acceptance, and GST awareness with GST acceptance.

\section{CONCLUSION}

In the current study, the competency level of the taxpayers is measured through GST literacy and GST awareness. GST literacy was measured based on two dimensions namely, GST knowledge and GST awareness. The results indicate that the school teachers are literate on the issues of GST implementation and GST system in Malaysia. A literate teacher is a teacher that that understands and has knowledge on GST system in Malaysia. The teachers understand the GST terminology, mandatory turnover limit which requires business to register under GST, types of GST, GST standard rate, pricing requirement with relevant to GST displayed and tax reformation process.

The results also reveal that teachers have high level of awareness on GST implementation in Malaysia. High awareness reflects that they are aware of receiving receipt upon purchase GST items, aware that the rate charged must be reflected on the receipts and aware of the responsibility to report to respective author of any deception by sellers. The respondents also aware that the GST knowledge and GST education are important for secondary school students, as they are the future taxpayers. A literate teacher is a person who able to read and understand GST system in Malaysia.

The acceptance level is divided into three categories namely, high, medium and low acceptance. The results show a moderate acceptance level of GST implementation in Malaysia among the secondary school teachers. This study suggests that the level of acceptance of the 
secondary school teachers before and after GST implementation remains unchanged. This may due to the stage of GST implementation has not reached a period of one year when this study was conducted.

The taxpayers moderately accept GST implementation in Malaysia as they believe that GST contributes to the government's revenues. They believe that unclear objectives and lack of information provided by the government led them to have a low level of acceptance. They also moderately agree on the issues benefits and fairness that GST can offer to the consumers, businesses and country.

The results also found that the GST literacy level of the secondary school teachers affect their GST acceptance level. This study suggests that the level of literacy among the secondary school teachers on GST implementation has a positive effect their level of acceptance.

This study suggests that future study should examine the relationship of GST literacy levels and GST acceptance levels of teachers or educators in other states in Malaysia using a larger sample. More time should be allocated to collect and analyse the data. The future study could use a combination of instruments such as interviews, focused group interviews and documents analysis. In addition, the interaction between GST literacy level and GST compliance level in the perspective of gender, races, age, income levels, and other variables can be conducted.

\section{REFERENCES}

Ahmad, R., Ahmad, R., \& Alwie, S. M. (2015). Instilling Malaysian Consumers' Mind-Set in Accepting GST: An Analysis on the Effectiveness of Communication used by the Government. Innovation, Finance, and the Economy, 1, 121-134. doi: 10.1007/978-3319-15880-8_10

Al-Mamun, A., Entebang, H., Mansor, S. A., Yasser, Q. R., Nathan, T. M., \& Rahman, M. A. (2014). The Impact of Demographic Factors on Tax Compliance Attitude and Behavior in Malaysia. Journal of Finance, Accounting and Management, 5(1), 109-124.

Alappatt, M., \& Shaikh, J. M. (2014). Forthcoming Procedure of Goods and Services Tax (GST) in Malaysia. Issues in Business Management and Economics, 2(12), 210-213.

Bahari, A. B. M., \& Ling, L. M. (2009). Introducing Tax Education in Non-Accounting Curriculum in Higher Education: Survey Evidence. Journal of Financial Reporting \& Accounting, 7(1), 37-51.

Band, D. (1992). Corporate Governance: Why Agency Theory is not Enough. European Management Journal, 10(4), 453-459.

Bardai, B. (1992). Tax Illiteracy in Malaysia: Problems Solutions. Journal of ACCAMADIA, 7-31.

Benge, M., Pallot, M., \& Slack, H. (2013). Possible Lessons For The United States From New Zealand's GST. National Tax Journal, 66(2), 479-498.

Bhushan, P., \& Medury, Y. (2013). Determining Tax Literacy of Salaried Individuals - An Empirical Analysis. IOSR Journal of Business and Management, 10(6), 76-80. 
Book, L. (2003). The Poor and Tax Compliance: One Size Does Not Fit All. Kansas Law Review, 51, 1145.

Breen, J., Bergin-Seers, S., Roberts, I., \& Sims, R. (2002). The Impact of the Introduction of the GST on Small Business In Australia. Asian Review of Accounting, 10(1), 89-104.

Choo, T. S. (2014). The battle for GST acceptance, The Sun Daily. Retrieved from http://www.thesundaily.my/node/251014

Cullis, J., \& Jones, P. (1992). Public Finance and Public Choice: Analytical Perspectives: McGraw-Hill International (UK) Limited.

Cvrlje, D. (2015). Tax Literacy as An Instrument of Combating and Overcoming Tax System Complexity, Low Tax Morale and Tax Non-Compliance. The Mactotheme Review, 4(3), 156-167.

Fadzell, A. (2015). By-election will show if GST accepted or not, The Sun Daily. Retrieved from http://www.thesundaily.my/news/1406721

Fatt, C. K. (2006). Towards goods and services tax in Malaysia : A Preliminary Study. Business \& Economics Society International Conference, 1-17.

Field, A. (2013). Discovering Statistics Using IBM SPSS Statistics (4th ed.). London: SAGE Publications Inc.

Fishbein, M., \& Ajzen, I. (1975). Belief, Attitude, Intention, and Behavior: An Introduction to Theory and Research Reading, MA: Addison-Wesley.

Hair, J. F., Black, W. C., Babin, B. J., Anderson, R. E., \& Tatham, R. (2006). Multivariate Data Analysis (6th ed.): Upper Saddle River, NJ: Prentice-Hall.

Hooper, P., \& Smith, K. A. (1997). A value-added tax in the U.S.: An argument in favor. Business Horizons, 40(3), 78-83. doi: http://dx.doi.org/10.1016/S0007-6813(97)90056$\underline{2}$

James, S. (2000). VAT/GST: The UK Experience Revisited. Revenue Law Journal, 10(1), 7287.

James, S., \& Alley, C. (2008). Successful Tax Reform: The Experience Of Value Added Tax In The United Kingdom And Goods And Services Tax In New Zealand. Journal of Finance and Management in Public Services, 8(1), 35-47.

Jenkins, G. P., \& Khadka, R. (1998). Value Added Tax Policy And Implementation In Singapore. International Bureau of Fiscal Documentation, 9(2), 35-47.

Kamaluddin, A., \& Madi, N. (2005). Tax Literacy and Tax Awareness of Salaried Individuals in Sabah and Sarawak. Journal of Financial Reporting and Accounting, 3(1), 71-89.

Kumar, N. (2014). Goods And Services Tax in India: A Way Forward. Global Journal of Multidisciplinary Studies, 3(6), 216-225. 
Latiff, A. R. A., Noordin, B. A. A., Omar, M. R. C., \& Harjito, D. A. (2005). Tax Literacy Rate Among Taxpayers: Evidence From Malaysia. Jurnal Akuntansi \& Auditing Indonesia, 9(1), 1-11.

Lindholm, R. W. (1970). The Value Added Tax: A Short Review Of The Literature. Journal of Economic Literature, 8(4), 1178-1189.

Loo, E. C., Evans, C., \& McKerchar, M. (2010). Challenges in Understanding Compliance Behavior of Taxpayers in Malaysia. Asian Journal of Business and Accounting, 3(1), 145-161.

Madi, N., \& Kamaluddin, A. (2003). Tax literacy among salaried individuals in Sarawak. Bureau of Research and Consultancy MARA University of Technology Shah Alam Selamgor.

Madi, N., Kamaluddin, A., Janggu, T., Ibrahim, M. B. A., Samah, A. B. A., \& Jusoff, K. (2010). Tax Literacy among Employees: Sabah and Sarawak's Perspective. International Journal of Economics and Finance, 2(1), 218-223.

Mahdavi, S. (2008). The level and composition of tax revenue in developing countries: Evidence from unbalanced panel data. International Review of Economics \& Finance, 17(4), 607-617.

Mansor, N. H. A., \& Ilias, A. (2013). Goods and Services Tax (GST): A New Tax Reform in Malaysia. International Journal of Economics Business and Management Studies, 2(1), 12-19.

McGowan, J. R., \& Billings, B. A. (1997). An Analysis of the European Community VAT: Implications for U.S. Tax Policy. journal of International Accounting Auditing \& Taxation, 6(2), 131-148.

Moomal, A., \& Zakaria, Z. (2014). Awareness, Acceptance and Expectations of Malaysia Consumers Towards Good and Service Tax (GST). Journal of Contemporary Management Sciences, 4(2), 15-27.

Muijs, D. (2004). Doing Quantitative Research in Education with SPSS: SAGE Publications Ltd.

Narayanan, S. (2014). THE IMPACT OF THE GOODS AND SERVICES TAX (GST) IN MALAYSIA: LESSONS FROM EXPERIENCES ELSEWHERE (A NOTE). The Singapore Economic Review, 59(1), 1-15.

Nathan, T. M., \& Rahman, M. A. (2014). The Impact of Demographics Factors on Tax Compliance Attitude and Behavior in Malaysia. Journal of Finance, Accounting and Management, 5(1), 109-124.

Nurhayati, N., Halimatusadiah, E., \& Diamonalisa. (2015). Influence of tax officer service quality and knowledge of tax on individual taxpayer compliance in tax office (kpp) Bojonagara Bandung. International Journal of Applied Research, 1(8), 805-809. 
Olatunji, O. C. (2013). Value Added Tax (VAT) and Inflation in Nigeria (1990 to 2003). Asian Journal of Humanities and Social Sciences (AJHSS), 1(1), 123-135.

Oxford Student's Dictionary of English. (Ed.) (2007). Malaysia: Oxford Fajar Sdn. Bhd.

Palil, M. R. (2005). Taxpayers Knowledge: A Descriptive Evidence On Demographics Factors In Malaysia. Jurnal Akuntansi \& Keuangan, 7(1), 11-21.

Palil, M. R., Akir, M. R. M., \& Ahmad, W. F. W. (2013). The Perception of Tax Payers on Tax Knowledge and Tax Education with Level of Tax Compliance: A Study the Influences of Religiosity. ASEAN Journal of Economics, Management and Accounting, 1(1), 118129.

Palil, M. R., \& Ibrahim, M. A. (2011). The Impacts of Goods and Services Tax (GST) on Middle Income Earners in Malaysia. World Review of Business Research, 1(2), 192206.

Palil, M. R., Ramli, R., Mustapha, A. F., \& Hassan, N. S. A. (2013). Elements of Compliance Costs: Lesson from Malaysia Companies towards Goods and Services Tax (GST). Asian Social Science, 9(11), 135-147.

Pallant, J. (2011). SPSS SURVIVAL MANUAL A step by step guide to data analysis using SPSS (4th Ed.): Allen \& Unwin.

Rashid, E. R. B. A., Mohammed, N. F., \& Saheh, N. M. (2005). EXPLORING LEVEL OF AWARENESS OF SMALL AND MEDIUM SIZED ENTERPRISES TOWARDS GOODS AND SERVICES TAX IMPLEMENTATION IN MALAYSIA Research Universiti Teknology MARA (UiTM).

Rauf, J. b. A., \& Yusuf, M. Z. b. M. (2014). Guide on Pre-Tertiary Education. (03-88822111).

Royal Malaysia Customs Department. (15th February 2013). Understanding GST. Retrieved 3rd September, 2015, from http://gst.customs.gov.my/en/gst/Pages/gst un.aspx

Royal Malaysia Customs Department. (2015). Goods and Services Tax (GST). In R. M. C. Department (Ed.).

Saira, K., Zariyawati, M. A., \& Yoke-May, L. (2010, 13-15 July 2010). An Exploratory Study of Goods and Services Tax Awareness in Malaysia. Paper presented at the Proceedings Seminar on Nasional Resilience (SNAR 2010) "Political Managements and Policies in Malaysia", Bayview Hotel Langkawi.

Sekaran, U., \& Bougie, R. (2013). Research Methods for Business: A Skill-Building Approach (6th ed.): John Wiley \& Sons Ltd.

Shamsuddin, A., Ruslan, M. I. M., Halim, A. A., Zahari, N. F., \& Fazi, N. F. M. (2014). Educators' Awareness and Acceptance Towards Goods and Services Tax (GST) Implementation in Malaysia: A Study in Bandar Muadzam Shah, Pahang. International Journal of Business, Economics, and Law, 4(1), 1-10. 
Sumartaya, D., \& Hafidiah, A. (2014). The influence of taxpayers's awareness and tax morale toward tax evasion. International Journal of Business, Economics, and Law, 5(1), 6068 .

Tan, L. M., \& Chin-Fatt, C. (2000). The Impact of Tax Knowledge on the Perceptions of Tax Fairness and Attitudes Towards Compliance. Asian Review of Accounting, 8(1), 44-58.

The Star. (2015, 23rd August 2015). GST will help country when oil prices fall, says Najib, The Star. Retrieved from http://www.thestar.com.my/News/Nation/2015/08/23/NajibUmno-GST-good-for-revenue/

The Star Online. (2013). Getting GST acceptance will be taugh, The Star Online. Retrieved from http://www.thestar.com.my/Business/Business-News/2013/05/25/Getting-GSTacceptance-will-be-tough-Minister-hints-at-commitment-to-reduce-corporate-andpersonal/?style $=$ biz

Wolk, H. I., Dodd, J. L., \& Tearney, M. G. (2004). Accounting Theory: Conceptual Issues in a Political and Economic Environment (6 ed.): Thomson South Western. 